\title{
Najnowsze osiągnięcia w radioterapii adaptacyjnej MRgRT w świetle doniesień zaprezentowanych podczas konferencji ESTRO 37
}

\section{Urszula Sobocka-Kurdyk ${ }^{1}$}

${ }^{1}$ Zakład Radioterapii III, Wielkopolskie Centrum Onkologii im. Marii Skłodowskiej-Curie w Kaliszu

\section{Streszczenie}

Celem niniejszej pracy było omówienie najnowszych doniesień o radioterapii adaptacyjnej na podstawie prezentacji ustnych oraz plakatowych zaprezentowanych podczas 37. konferencji Europejskiego Towarzystwa Radioterapii i Onkologii - ESTRO (ang. European Society for Radiation and Oncology).

\begin{abstract}
The aim of this paper was to highlight the new developments in adaptive radiotherapy. The described issues were based on selected reports presented during ESTRO 37 conference in Barcelona.
\end{abstract}

Stowa kluczowe: radioterapia adaptacyjna; rezonans magnetyczny; MR LINAC; IGRT; MR-only workflow

Key words: adaptive radiotherapy; magnetic resonance; MR-RT hybrid ; IGRT; MR-only workflow

\section{Wstęp}

Możliwość zastosowania obrazowania metodą rezonansu magnetycznego (ang. magnetic resonance imaging; MRI) w radioterapii adaptacyjnej było jednym z najczęstszych zagadnień omawianych w trakcie konferencji ESTRO 37 zarówno podczas wystąpień ustnych, jak i sesji plakatowych. Coraz częściej mówi się o systemie radioterapii prowadzonej wyłącznie w oparciu o obrazowanie MR (ang. MR-only RT), z uwagi na możliwość otrzymania lepszego rozróżnienia tkanek miękkich w porównaniu z tomografią komputerową (ang. Computed Tomography; CT) [1, 2].

Adres do korespondencji

Urszula Sobocka-Kurdyk

Zakład Radioterapii III,

Wielkopolskie Centrum Onkologii im. Marii Skłodowskiej-Curie w Kaliszu

Telefon. +48 623322549

e-mail: urszula.sobocka-kurdyk@wco.pl 
Wyeliminowanie z procesu radioterapii tomografii komputerowej i wprowadzenie hybrydy MR-RT (połączenie akceleratora liniowego z rezonansem magnetycznym) umożliwia codzienną kontrolę ułożenia pacjenta bez deponowania dodatkowej dawki promieniowania jonizującego, a także adaptację planu leczenia na podstawie obrazów MR [2]. Należy jednak mieć na uwadze ograniczenia i wymagania, jakie niesie ze sobą zastosowanie takiej metody:

- możliwość pojawienia się geometrycznych zniekształceń obrazu, które mogą powstawać z niejednorodności stałego pola magnetycznego, a także nieliniowości gradientów,

- konieczność wprowadzenia cewek nadawczo-odbiorczych, które zagwarantują pozycję terapeutyczną pacjenta,

- brak informacji o gęstości elektronowej, która niezbędna jest do kalkulacji rozkładu dawki promieniowania jonizującego w napromienianej objętości [1, 2, 3, 4].

Jednym zgłównych wyzwań związanych z prowadzeniem radioterapii adaptacyjnej w oparciu o obrazowanie MR (ang. adaptive MR Guided Radiotherapy; adaptive $M R g R T$ ) jest utworzenie tzw. syntetycznych CT (sCT), czyli wygenerowanie map gęstości elektronowych na podstawie danych uzyskanych z obrazowania MRI $[1,3]$. Cały schemat postępowania w radioterapii adaptacyjnej MRgRT możemy podzielić na etapy:

- Akwizycja obrazów MRI

- Wygenerowanie sCT

- Wyznaczenie objętości napromienianej i narządów krytycznych

- Wygenerowanie planu leczenia

- Zatwierdzenie planu leczenia

- Kontrola jakości planu leczenia [3].

\section{Generacja syntetycznego CT}

Główny problem podczas generowania sCT na podstawie obrazów MR wynika z uzyskiwania podobnego natężenia sygnału MR tkanek o różnych gęstościach (np. płuca i kości). Związane jest to z fizyczną podstawą obrazowania za pomocą MR, która koreluje z gęstością protonową tkanek i relaksacją magnetyczną $[1,5]$. Poniżej zostały opisane trzy główne metody generowania sCT.

(a) Metoda bazująca na wokselu (ang. volumetric picture element; voxel) wykorzystuje przede wszystkim informacje o intensywności wokseli w obrazach MR, aby przypisać im gęstość elektronową. Metoda ta nie uwzględnia jednak informacji o ich położeniu. Zwykle podejście bazujące na wokselu wykorzystuje się podczas tzw. uczenia maszynowego (ang. machine learning) do utworzenia algorytmu. Przygotowany optymalny model jest w tym wypadku stosowany na pozostałych danych MRI w celu przewidywania i przypisywania gęstości elektronowej $[1,3]$.

(b) Metoda bazująca na atlasach anatomicznych polega na dopasowaniu położenia wokseli MRI pacjenta do odpowiedniej lokalizacji we wcześniej utworzonym atlasie. Dla danego pacjenta zostaje wykonane obrazowanie zarówno metodą CT, jak i MRI, które są ze sobą następnie porównywane. Atlas zawiera znaną korelację pomiędzy wokselami MRI a np. typem tkanki i gęstością elektronową [1, 3, 4].

(c) Metoda bazująca na gęstości objętościowej (ang. bulk density assignment) wykorzystuje dokładną segmentację struktur kostnych i tkanki miękkiej. Polega na akwizycji wielu obrazów, różniących się między sobą zastosowanymi sekwencjami MR. W poszczególnych przedziałach (kości i tkanek miękkich) korelacja między natężeniami sygnału MR i gęstością elektronów jest znacznie lepsza. W rezultacie wokselom można przypisać wartości gęstości w oparciu o ich intensywność. Syntetyczne CT w tej metodzie otrzymuje się w dwóch etapach. Początkowo zawartość obrazu MR dzieli się na pięć klas (powietrze, tkankę tłuszczową, tkankę dobrze uwodnioną, istotę gąbczastą kości i istotę zbitą kości). Następnie do każdego woksela przypisuje się wartość gęstości elektronowej w oparciu o wartości tablicowe $[3,5]$. 


\section{Wyznaczenie konturów}

Obrazowanie MRI, przed zastosowaniem hybryd MR-RT, było wykorzystywane głównie jako pomocnicze do wyznaczenia objętości napromienianej na skanach CT po wcześniejszej fuzji obrazów. Obecnie systemy pracujące w oparciu o MR-only RT umożliwiają skanowanie pacjenta bezpośrednio przed lub w trakcie leczenia i dostosowanie planu zgodnie ze zaktualizowanymi informacjami na temat anatomii pacjenta dla tej samej frakcji leczenia [6]. Do wyznaczenia nowych konturów targetu i narządów krytycznych na skanach MR możemy wybrać poniższe możliwości:

- automatyczną segmentację na obrazach MR w oparciu o atlasy

- ręczne wyznaczenie konturów na obrazach MR

- przeniesieniekonturów po wykonaniu fuzji krzywoliniowej pomiędzy skanami MR (zarejestrowanymi przed frakcją napromieniania) a obrazowaniem referencyjnym [3].

\section{Plan leczenia} w oparciu o:

Kalkulację rozkładu dawki podczas adaptacji planu leczenia w radioterapii MRgRT można wykonać

- pełną optymalizację na podstawie nowych skanów MR i wyznaczonych konturów

- optymalizację z zachowaniem gradientu dawki w bliskim otoczeniu od PTV (uwzględniony zostaje kontur tylko PTV)

- optymalizację z uwzględnieniem konturów narządów krytycznych znajdujących się w pewnej odległości od PTV [3].

\section{Dostępna aparatura}

Obecnie dostępne urządzenia będące hybrydą MR-RT oferowane są między innymi przez firmy ViewRay (MRIdian-Linac) czy też Elekta (Unity). Każdy z systemów stanowi połączenie wysokoenergetycznego akceleratora liniowego ze skanerem MR.

Aparat MRIdian-Linac wyposażony jest w dzielony magnes nadprzewodzący 0,35 T. Taka konstrukcja zmniejsza interakcję między akceleratorem liniowym a polem magnetycznym MR, przez co nie powoduje zniekształceń obrazu, ani nie zaburza dawki podczas radioterapii. Średnica okola wynosząca $70 \mathrm{~cm}$ umożliwia realizację procedury radioterapii nawet wśród pacjentów otyłych. Dodatkowo wysokoenergetyczna wiązka promieniowania fotonowego, generowanego w akceleratorze, kształtowana jest przez podwójny stos kolimatora wielolistkowego (ang. Multi Leaf Collimator, $M L C$ ). Taki układ kolimatora ma na celu zredukowanie obszaru półcienia wiązki, a przez to może mieć szczególne znaczenie w radioterapii stereotaktycznej. MRIdian wyposażone zostało w oprogramowanie SmartADAPT, dzięki któremu możliwa staje się adaptacja planu leczenia w oparciu o bieżącą pozycję guza, jak i narządów krytycznych, na podstawie otrzymanych skanów MR. Ponadto rozwiązanie SmartTARGET umożliwia wizualizację i śledzenie krawędzi guza, kontrolując realizację procesu napromieniania [7-9].

W aparacie Unity, opracowanym przez firmę Elekta, zastosowano skaner MRI o średnicy okola $70 \mathrm{~cm}$ i indukcji pola magnetycznego 1,5 T (dostarczony przez partnera - firmę Philips), który zapewnia wysokiej jakości obrazy MR. Akcelerator liniowy wyposażony został w układ kolimujący wiązkę złożony ze 16o listków MLC. Zaprojektowane oprogramowanie w połączeniu z aparatem Unity umożliwia spersonalizowaną adaptację planów leczenia, w oparciu o wizualizację w czasie rzeczywistym położenia i kształtu guza. Leczenie pierwszego pacjenta z wykorzystaniem aparatu Unity odbyło się 19 maja 2017 roku w Uniwersyteckim Centrum Medycznym w Utechcie [10-11].

\section{Badania naukowe}

Obecnie prowadzonych jest wiele badań naukowych z klinicznym wykorzystaniem hybrydy MRRT. Podczas konferencji ESTRO 37 zostały zaprezentowane m.in. badania porównawcze planów leczenia wygenerowanych na podstawie tradycyjnego obrazowania CT z planami utworzonymi na bazie sCT. 
Dane przedstawione w publikacji Wang et al. zostały zebrane dla grupy 11 pacjentów leczonych z powodu raka jelita grubego. W celu wygenerowania sCT z obrazów MR (sekwencja Dixon) połączono metodę atlasów anatomicznych i przypisania gęstości objętościowej. Zarówno w przypadku techniki 3D-CRT, jak i VMAT, plany leczenia utworzone w oparciu o sCT były równoważne z planami wygenerowanymi na konwencjonalnym CT (po uwzględnieniu tej samej liczby jednostek monitorowych). Średnia dozymetryczna różnica między utworzonymi planami była mniejsza niż 0,4\% [12]. Należy jednak pamiętać, iż porównanie zostało przeprowadzone dla niewielkiej ilości planów leczenia.

Dzięki możliwości obrazowania w czasie rzeczywistym i śledzenia zmian położenia guza w trakcie seansu radioterapii hybryda MR-RT, co może w przyszłości zostać wykorzystana do realizacji leczenia w oparciu o bramkowanie oddechowe. Rezultaty napromieniania czterech pacjentów z przerzutami do kości kręgosłupa w oparciu o obrazowanie MR w czasie rzeczywistym na aparacie Unity (Elekta) przedstawiono w pracy Raaymakers B. W. et al. Dokładność dozymetryczną planów leczenia (rozkłady dawek obliczone na podstawie sCT) oceniano na podstawie pomiarów za pomocą komory jonizacyjnej w specjalnym fantomie, a także filmów radiochromowych. Z przedstawionych danych wynika, iż odchylenia od zaplanowanej dawki wahają się od o,o\% do 1,7\% (w izocentrum). Podczas napromieniania stabilność pacjenta była monitorowana poprzez uzyskiwanie obrazów MR co 7 sekund, jednak nie zauważono zmian położenia objętości napromienianej, a jedynie drobne przesunięcia pozycji otaczających struktur. Całkowity czas potrzebny na realizację procedury, od momentu rozpoczęcia obrazowania pacjenta, poprzez adaptację planu leczenia i proces napromieniania, wynosił średnio 41 minut [13].

\section{Podsumowanie}

Podczas konferencji ESTRO 37 przedstawiono możliwości klinicznego wykorzystania MRI do adaptacji planów leczenia w radioterapii. W trakcie głównych sesji podkreślano, iż wprowadzenie hybrydy MR-RT pozwala na wysoką jakość obrazowania targetu i lepsze spersonalizowanie opieki nad pacjentami podczas każdorazowego seansu leczenia. Mimo oczywistych korzyści płynących z wprowadzenia MRgRT to całkowite wykluczenie CT i zastosowanie systemu MR-only RT niesie ze sobą pewne ryzyko. Jest ono związane przede wszystkim z poprawnością wyznaczenia gęstości elektronowych w oparciu o obrazowanie MR. Ponadto zaprezentowane wyniki badań zostały przeanalizowane dla prób o małej liczebności.

\section{Finansowanie/ Financial suport}

Artykuł został sfinansowany z grantu Wielkopolskiego Centrum Onkologii w Poznaniu, nr 10/2018(188); 20/03/2018/ORK/WCO/013. / This work was supported by the Greater Poland Cancer Centre, grant no. 10/2018(188); 20/03/2018/ORK/WCO/013.

\section{Piśmiennictwo / References}

[1] Edmund J.M., Nyhom T., A review of substitute CT generation for MRI-only radiation therapy, Radiation Oncology 2017; 12 (1): 12-28

[2] Palacios M., In room MR imaging, session - New developments in online adaptive MRgRT, materiały zjazdowe konferencji ESTRO 37,Barcelona, 20 - 24.04.2018

[3] Nill S., Oelfke U., Daily replanning strategies, session - New developments in online adaptive MRgRT, materiały zjazdowe konferencji ESTRO 37,Barcelona, 20 - 24.04.2018

[4] Skórska M., Nowe technologie wykorzystywane $w$ procesie teleradioterapii $w$ świetle doniesień zaprezentowanych podczas konferencji ASTRO 57 w San Antonio, Zeszyty Naukowe WCO, Letters in Oncology Science 2016; 13(1):24-29

[5] Köhler M., Vaara T., Groote M. V, Hoogeveen R., Kemppainen R., Renisch S., MR-only simulation for radiotherapy planning, Philips White Paper 2015

[6] Kieselmann J. P., Kamerling C. P., Burgos N., Menten M. J., Fuller C. D., Nill S et al., Geometric and dosimetric evaluations of atlas-based segmentation methods of MR images in the head and neck 
region, Phys. Med. Biol. 2018; 63145007

[7] https://viewray.com/discover-mridian/ (dostęp z dnia 12.03.2019)

[8] Yang Y., MRI on a MR Guided RT System, materiały zjazdowe konferencji ESTRO 37, Barcelona, 20 - 24.04.2018 https://viewray.com/clinical-spotlight/scientific-presentations/ (dostęp $\mathrm{z}$ dnia 13.03.2019)

[9] Debus J., Installation and Clinical Commissioning of a $M R$ Linac, materiały zjazdowe konferencji ESTRO 37, Barcelona, 20 - 24.04.2018 https://viewray.com/clinical-spotlight/scientific-presentations/ (dostęp z dnia 13.03.2019)

[10] https://www.elekta.com/unity/ (dostęp z dnia 12.03.2019)

[11] Matulewicz Ł., Elekta Unity - integracja przyspieszacza liniowego ze skanerem MR 1,5T, Inżynier i Fizyk Medyczny 2017; 6: 130-132.

[12] Wang H., Du K, Qu J, Chandarana H., Das I. J., Dosimetric evaluation of magnetic resonance-generated synthetic CT for radiation treatment of rectal cancer, PLoS ONE 2018, 13(1).

[13] Raaymakers B. W., Jürgenliemk-Schulz I. M. , Bol G. H. , Glitzner M. et al., First patients treated with a 1.5 T MRILinac: clinical proof of concept of a high-precision, high-field MRI guided radiotherapy treatment. Phys. Med. Biol. 2017; 62: 41-50. 